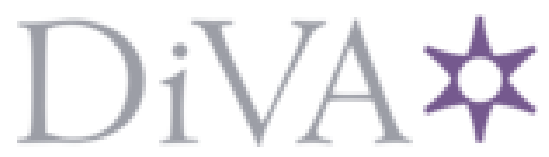

http://www.diva-portal.org

\title{
Preprint
}

This is the submitted version of a paper published in First Monday.

Citation for the original published paper (version of record):

Svensson, J. (2014)

Activist Capitals in Network Societies.: Towards a Typology for Studying Networking Power in Contemporary Activist Demands.

First Monday, 19(8)

http://dx.doi.org/10.5210/fm.v19i8.5207

Access to the published version may require subscription.

N.B. When citing this work, cite the original published paper.

Permanent link to this version:

http://urn.kb.se/resolve?urn=urn:nbn:se:uu:diva-229498 


\title{
Activist Capitals in Network Societies
}

\section{Towards a typology for studying networking power within contemporary activist demands}

Jakob Svensson, Uppsala University

jakob.svensson@im.uu.se

\begin{abstract}
Network societies are characterized by social media, media that are supposed to level out power hierarchies, making political participation more inclusive and equal. By developing a typology for studying networking power within activist demands in network societies, such technooptimistic/deterministic assumptions are questioned. This typology is based on Bourdieu's conceptual framework of social fields, habitus and capitals and revolves around participating, mobilising, connecting, and engaging capital and how these intersects, overlaps and are used for negotiating recognition which I argue is of pivotal importance in for upholding core positions and thus in todays activist demands. Such core positions are related to networking power, i.e. knowing how and being in a position to network in order to decide about courses of events in the organisation of the demand/ social field and its actions. This largely theoretical account is exemplified from a (n)ethnographic study of a middle-class activist setting in southern Stockholm using online communication platforms in tandem with more traditional offline activist participation to organise and mobilise participation.
\end{abstract}




\section{Introduction}

One day I got a message via Facebook suggesting I should sign an online petition against the plans to demolish the old community-run (but city-owned) bathhouse two blocks away from where I lived in southern Stockholm. Since I had enjoyed the bathhouse and their different activities, I signed the petition, joined the Facebook-group, started to follow their Twitter feeds, and added many of the participants as Facebook-friends. I soon came to realise that online visibility through practices of updating on social media platforms such as Facebook and Twitter would get me closer to some of the activists. By echoing popular arguments through practices of retweeting and through posting encouraging entries on some of the core activists Facebook profiles, I was not primarily showing my sympathy for what has been understood as participatory values of activist groups semipublically displaying their communication on social media platforms (see Jenkins, 2006; Bruns, 2008; Shirky, 2009). What I did was to reinforce core positions of certain activists. It became apparent to me that activists using social media platforms are not necessarily equal as the technooptimist/determinist discourse around social media participation suggests, that social media platforms are supposed to level out power hierarchies through lowering the threshold of participation and mobilising political action (as Shirky, 2009 and Castells, 2012 have argued). In this article I challenge such assumptions by suggesting a typology for analysing power asymmetries within activist demands in network societies and discussing what role social media platforms play for upholding these. Before outlining to this typology, I will first attend to some conceptual clarifications and present the bathhouse demand that will be used to exemplify my argument.

Activism is approached as a form political participation. Acknowledging the widening understanding of political participation (see Bengtsson, 2008, p. 116; Esaiasson and Westholm, 2006, p. 15), activism could be defined as participation from outside representative democratic institutions, but with an outspoken aim to influence them (Author). It is argued that activism is 
important for broadening political participation beyond established power elites (Bennett and Amoshaun, 2009). Indeed, participatory democratic theory has its roots in a broad understanding of politics as encompassing areas beyond the Parliament. Contemporary representative democracies cannot include all political demands, since majority decision-making always favours one over another (Mouffe, 2005). Hence, it becomes apparent already here that power cannot be left out of the equation since activist participation is understood as revolving around excluded demands (see also Carpentier, 2011; Fuchs, 2014, p. 55).

Laclau's (2005, pp. 73-74) splitting of groups into smaller units of demands - as presenting claims to a certain order - further contributes to this understanding of activism. Demands include both social movement types of participation and short-time commitment to single issues, the two types of political action that has come to dominate the discussion of activist participation. A demand may be formed into a more long-term social movement, or a single-issue campaign that disperses once the demand has been met (or considered lost). For example, people in southern Stockholm started to rally around a rather temporary commitment to a single issue, saving a bathhouse. Some of the participants continued their engagement though by forming a local lobby group SÖFÖ (Södra Förstaden, the Southern Suburb).

In this article the focus is on participation in activist demands in network societies. But how are we to understand network societies? In Castells' (2000) famous work, he uses the network as an intersectional concept for overcoming boundaries between society and technology. He describes a tendency to organise processes and functions as networks, the network thus becoming the social morphology of society, influencing everything from processes of production to individual experiences, power and culture (2000, p. 519). Network society therefore has been defined as a social formation with an infrastructure of social and media networks enabling its prime mode of 
organisation at all levels, individual, organisational, societal and global (van Dijk, 2006 pp. 19-20, 27). According to van Dijk (2006, pp. 2, 23), networks are becoming the nervous system of our society and we can expect them to influence our entire life. It is important to remember when discussing network societies that complex social networks have always existed. Recent developments in communication technology have however made the social network a more dominant form of social organisation (Wellman, 2001).

Social media stands out as a defining feature of network societies around which practices are organised, demands are communicated and individuality is negotiated. But how are we to understand social media? I have approached social media as communication platforms where the user him/ herself is able to contribute to the platforms content. Here I rely more on O'Reilly (2005) general definition of web 2.0 than Ellison \& boyd's (2007) popular, but more specific, delineation of social network sites (SNS). In my research it has been important to include both interactive and networking functions of social media (i.e. possibilities for user-centric multipath communication and collaboration, what is often implied as the "social" in social media, which is a very narrow understanding of the social, see Fuchs, 2014, pp. 7, ch. 2) without for that sake downplay their broadcasting functions that continue to be central for social media practices (especially among groups and individuals seeking visibility and to create public opinion for a political demand). In this way my approach resembles Jenkins, Ford \& Green's (2013) recent account of social media as "spreadable". Spreading I believe is a more accurate description of what is happening on social media than the often-used verb sharing. But in contrast to Jenkins and co-authors I am more critical towards supposed empowering potentials of such spreading (see Fuchs, 2014, 53-54, for an in-depth criticism of their account). To avoid a deterministic or an overtly uncritical understanding of social media platforms, I lean towards Kaplan and Haenlein's (2010, p. 60) definition of social media as internet-based applications that build on the ideological and technological foundations of web 2.0. 
Indeed, media platforms have a dynamic relationship between the social and the technical (Feenberg 2010).

In network societies our communities become increasingly technologically mediated (Andersson and Jansson, 2012, p. 106). In activist demands using internet-based social media platforms, communication practices entangle with the demands' organisational structure and identity to the point that they are hard to separate (Breindl, 2012). Since network societies have emerged largely because of media networks, a study of activist demands in such societies will inevitably put emphasis on practices of social media use, even though these are becoming increasingly hard to separate from the offline, see Baym, 2010; Chadwick, 2013. In the bathhouse demand for example activists relied heavily on social media platforms for communication, organisation and mobilisation, in tandem with more traditional offline methods (such as rallies and demonstrations).

Numerous studies have focused on how activists use the internet to mobilise support and organise themselves and their demands (see Breindl, 2012, for an overview). Some argue that internet-based organisation facilitates more horizontal and equal distribution of power, and that politics and participation become more accessible because the internet is supposed to lower the threshold, even for groups previously excluded from the political arena (Jenkins, 2006; Bruns, 2008; Shirky, 2009). While acknowledging that the landscape of power is changing in network societies, there is no reason to believe that increasing organisation in (media) networks will cause a society devoid of power relations. Elias made this argument already in 1939. When people become increasingly dependent on each other, a need to attune conducts arises (Elias 1998/1939, pp. 51-52). Thus, the interdependence of people in network societies corresponds with the increasing importance of managing behaviour (see also van Dijk, 2006; Breindl and Gustafsson, 2011). Power has to do with who can influence, and who is allowed to influence the course of events (Fuchs, 2014, p.70, 218). 
Hence, power concerns the interdependence between people that today has come to revolve around networking because of increased network organisation and social media use in network societies. What I propose to label networking power revolves around being in a position, or being positioned in a network to exert influence by setting the agenda and defining the reality as well as getting the attention for the information you spread. The underlying argument here being that a democratisation of opportunities for displaying information, information that may or may not spread, does not imply the levelling out of differences between users. As I hope will become apparent towards the end of this article, everyone do not have the same skills, or are in the equal position to spread information, set the agenda or define the situation/ reality and in this way influence the course of events here in an activist demand.

Of pivotal importance for my argument is recognition. Who is allowed to exert influence and who is heard in the increasing information buzz in network societies depend to a large extent on recognition. Here social media may be conceived of as sites of power struggles since they have specific mechanisms (algorithms) for the generation of reputation (see van Dijck, 2013, pp. 13, 62) which in turn determines who's information will get noticed or not. Hence, networking power intersects with status, recognition, legitimation and asymmetries between users in terms of visibility and attention (here my account differs from Castells, 2009, idea of networking power as inclusion in important global networks). This is what I intend to study in this article, focusing on relations of power between people within activist demands in network societies. To do this I will exemplify with the bathhouse demand in southern Stockholm. Hence, I will start with a short presentation of this before attending to the typology for studying networking power. 


\section{The Bathhouse Demand}

I will illustrate this largely theoretical account with examples from a (n)ethnographic study of a contemporary middle-class activist demand, saving a local bathhouse from destruction. This demand engaged (mostly) inhabitants in the southern Stockholm suburbs of Aspudden and Midsommarkransen. They are among the oldest suburbs, situated close to the waterfront, with buildings dating back to the end of the $19^{\text {th }}$ century, and located just two subway stops away from the inner city. The two suburbs are populated by an educated and politically aware middle-class. Nearby Midsommarkransen is located the University College of Arts, Crafts and Design, Konstfack, and in Midsommarkransen you also find the community run Cinema, Tellus, where members organise activities, show movies, documentaries as well as children blockbusters. Hence, the suburbs are popular both with urban middle-aged couples looking for bigger apartments without having to go too far away from the inner city, as well as with youngsters studying at, or attracted to, the creative atmosphere around Konstfack. The suburbs are a political stronghold of the Green Party with up to 23 per cent voting for them in the 2010 national elections (compared to seven per cent nationally).

Inhabitants in these suburbs started to rally already in 2007, first to renew their bathhouse in Aspudden, and later to save it from destruction. Together with traditional offline activist campaigns, online social media platforms were used to call for engagement, to spread information and to gather support for keeping the bathhouse. The bathhouse was demolished despite of heavy protests, campaigns and even an occupation. Most activities took place during the couple of months leading up to the overtaking and demolition of the bathhouse late November 2009. Some of the bathhouse activists continued their participation in SÖFÖ (Södra Förstaden, the Southern Suburb), a group that has continued to act in the suburbs against development plans, for the preservation green areas and playgrounds among other things. 
Concerning social media platforms the activists used a blog during the battle for the bathhouse through which they disseminated information, mobilised participation and mocked municipal politicians. During October and November 2009, the activists also used a Twitter-feed, mostly to spread information on activities as well as a means to mobilise participation. For quick mobilisation activist used a text-messaging list. For more lengthy comments, activists posted both on the blog as well as on a Facebook-group Rädda Aspuddsbadet (Save the Aspudden bathhouse). SÖFÖ use both a Facebook-group and at Ning- community platform on which participants have their own profiles, can connect and message each other as well as start discussions, specialised groups, blogs et cetera.

The study of this activist demand article was conducted within a larger project researching rationales of political participation in network societies. In previous publications on this demand I have discussed the importance of the values of reflexive connectivity and responsiveness and how these values encouraged/demanded a social negotiation of activists' selves, something that was done through practices of updating (Author). Furthermore, I concluded that these values, largely connected to using online social media platforms, seemed to push/discipline activists to participate (Author). Revisiting my interview material and field notes I also conclude that the location itself, the southern suburbs, were important around which values were negotiated. Activists talked about a unique southern suburb character consisting of old buildings among green leafy areas as well as neighbours knowing each other and doing things together, such as running the Aspudden bathhouse and cinema Tellus. The bathhouse was frequently described as a non-commercial meeting place, run by the inhabitants for the inhabitants, a symbol of a cherished value of a location bound community of neighbours. Accompanying this was a value of being active, involved, to voice concerns and show support for the demand. But rather than to be reactive, participants should be proactive, i.e. do something and engage others. The individuals that were held in high regard were the engaged ones, 
so-called "fire starters" and activists who succeeded in engaging many others to the cause. These values are important if trying to understand practices positionings within the activist demand which leads to the next section.

\section{Positions and habitus within activist demands}

According to Bourdieu (1985, p. 724 and 1987, p. 2) agents are defined and act according to their position in social space. Here I depart from an assumption that how participants establish their position within a demand, structures the values of the demand and vice versa. Hence, the shared values (such as the ones briefly discussed above) should be analysed in intersection with how activists position themselves and others in relation to these. Bourdieu's conceptual framework of social fields, habitus and capitals are useful for such analysis.

Starting with social fields, Bourdieu is somewhat unclear about the differences between the terms social space, world, field and sub-field. In one instance he talks about the political field as consisting of sub-fields of parties and unions, which could lead one to argue that activism is a subfield within a larger political field (1985, p. 737). Unfortunately Bourdieu does not guide us how to delineate between fields and sub-fields here. But his definition of a social field can be connected to Laclau's understanding of demands. Bourdieu (1993, p. 16) defines a social field as a collection of people that gather around a common belief worth fighting for. Agents within the same field can be of different opinions; it is the belief that the fight is worth the effort that binds them together (1993, p. 17). In southern Stockholm, the fight for the bathhouse was the common demand that bound activists to each other as a field in the first place.

Of prime importance here, is that Bourdieu (1985, p. 724) describes a social field as a multidimensional space of positions and positionings. In this article I focus on two positions, belonging 
to the core and to the periphery with the assumption that core positions entails greater opportunities for setting the agenda for the demand and defining the situation in which the demand is operating in, and in this way exerting influence over activists positioned more to the periphery of the field, networking power in other words. Core/ periphery positions are also underlined by Castells (2009, pp. 26,34$)$ who argues that practices of positioning within a community are primarily used to determine core/ periphery positions. In online activist demands such positions have further been conceptualised by Breindl and Gustafsson (2011) as concentric circles of participation. Core activists are the leaders, setting up email lists, creating applications, being in charge of following the political process, analysing as well as orchestrating the campaign. Fuchs (2014, p.86, with reference to Gerbaudo, 2012) refers to such core-activists as soft leaders, choreographing protests by being in charge of most of the communication flow. More towards the periphery we have occasional contributors who follow what core activists (soft leaders) do and participate from time to time, and mere followers who are inscribed on discussion lists and possibly spread information, but do not actively contribute to the organisation of the campaign itself (Breindl and Gustafsson, 2011).

In southern Stockholm, and resonating with the value of being proactive rather than reactive as well as with the account of soft leadership, belonging to the core or the periphery was divided along lines of who updated/ engaged others and who were updated/ engaged by others. Being updated indicated a more peripheral position, while being in charge of doing the updating, indicated a more central position. This was clearly illustrated by one (core) activist when asked about her Facebook practices; she stated she received no information online, she gave information there. It is important to underline that core positions tend to be less stable today in network societies where participants rather unite around temporary demands (so called issue engagement - see Author). Nonetheless, by taking control of information spreading and negotiating recognition and visibility, social media platforms offer spaces for some to negotiate core positions and thus having priority in setting 
agendas and defining the reality. The question that arises, and that I will devote the remainder of this article, is how this is done.

To understand why certain activists come to be entrusted with, hold and maintain core positions, Bourdieu's concept of habitus is helpful. Habitus refers to socially learned dispositions, the sense of one's place, the luggage an agent carries with him/her, which in turn positions the agent in relation to language, culture, class and the future (Bourdieu, 1987, p. 5 and 1993, pp. 12-14). Andersson and Jansson (2012, p. 38) describe habitus eloquently as acquired knowledge that give the bearer a sense of an embodied navigation skill on the field in which he/she is acting. An agents habitus both have a bearing on the field, in terms of organising, structuring and determining how field practices are conceived (Bourdieu, 1993, p. 300), as well on the agent him/herself, by being connected to his/hers position within the field, providing meaning to practices and perceptions (Bourdieu, 2010/1984, p.166).

If we apply the concept of habitus to the bathhouse demand, core activists referred to experiences from solidarity and animal rights movements. Engagement in the cinema Tellus also seemed to have built both a sense of a southern suburb community feeling, as well as skills and knowledge for organising and mobilising participation (i.e. being proactive). Interviewed activists also referred to experiences from student councils, student nations and the scout movement and similar organisations. Talking to activists and asking about important skills and knowledge for their participation and how these had been acquired, many referred to previous experiences in such organisations, organisations that indicate that they have had a middle-class upbringing. Similarly, Breindl and Gustafsson (2011) argue that activists closer to the core often possess educational knowledge, social, technical and organisational skills. 
Habitus is thus also connected to class. Several studies have underlined that users from lower socioeconomic groups tend to be less skilled in using digital platforms, hence pre-existing inequalities are both reflected and perhaps increased online (DiMaggio et al. 2004; Hargittai 2008; Gui and Argentin 2011). A report from the OECD (2010) concluded that the digital divide in education is along lines of skills of use rather than access, i.e. between those with the competencies and skills to benefit from computer use and those without such competencies. Such skills and competencies are influenced by socio- economic factors (DiMaggio et al. 2004). Also Hargittai and Hinnant (2008) found that among American young adults (18-26 years old), those with higher levels of education and wealthier parents (i.e. habitus) used the web for more capital enhancing activities (see aslo Gui and Argentin's, 2011 study among high school classes in Italy). Hence, those coming from wealthier socio-economic backgrounds and with better education seems to be better equipped to manage and controlling their online activities to negotiate and reinforce core positions.

Habitus thus influences networking power. Here it is also important to underline timeliness and circulation of information (Chadwick, 2013, pp. 87, 190) i.e. knowing when to inform, when to delay, when to spread. Hence, to successfully navigate the social fields of contemporary network societies depends on networking skills, skills that are intertwined with our social learned dispositions (i.e. habitus). Such skills have a bearing on the field in terms of how practices are organised, structured and conceived. Concepts such as online social networking skills, networking skills and digital literacy have been elaborated in order to map differences among users and groups of users in their ability to process meanings of digital content, and why some are more successful than others in negotiating core positions online (Breindl and Gustafsson, 2011; Hsieh, 2012). I have myself previously underlined that online social networking requires a new form of competence in order to manage ones visibility online at the same time avoiding being subject for surveillance (Author). Breindl and Briatte (2013, p. 34) also talk about digital protest skills as the combination 
of social and technical skills aimed at online collective action. Charisma and social competencies could be conceived of as resources for networking. Studying activist core positions in southern Stockholm, it became apparent that their actual and perceived networking abilities, intertwined with their habitus, in turn were intertwined with previous achievements, active participation and successful mobilisation of others. All this leads me to Bourdieu's concept of capital. An agent's habitus and composition of capital can not be understood as apart, since the manner in which an agent uses capital(s) reveals how the agent acquired it and therefore also how the agent is predisposed to use it (Bourdieu, 2010/1984, pp. 58, 61).

\section{Activist Capitals in Network Societies}

Bourdieu (1993, p. 269) defines capital as a social relationship, an energy that exists and produces its effects within the field it is used. Capital represents a power over the field "like aces in a game of cards that define the chances of profit in a given field at a given moment" (Bourdieu, 1985, p. 724). Profit here is to be understood as positions more to the core of a demand (or field to use Bourdieu's terminology). The notion of capital is related to practices of positioning because capital use cannot be understood without reference to the agent's habitus, position within the field, and in turn, the field position is dependent on the specific capital the agent can accumulate (Bourdieu, 1993, p. 269).

There have been many attempts to outline internet specific capitals, also by references to Putnam's (2000) often cited elaborations of Bourdieu's social capital. Ellison et al. (2011) for example discusses online social capital, or socio-technical capital, as based on technological affordances. One of the most detailed accounts is Urry's (2007) outline of network capital. He argues that contemporary societies are more and more organised around the value of circulation - mobilities and by investigating how social relations change from such mobilities, he discerns an ability to 
form and sustain networks, something he labels network capital (Urry, 2007, pp. 196-197). This is about the potential of being mobile and connected at the same time, the capacity to engender and sustain social relationships with those people who are not necessarily geographically proximate but do generate emotional, financial and practical benefits. According to Urry (2007, p. 198) network capital is a product of increasing possibilities of relations between individuals afforded by travel and communication technologies. The importance of values of connectivity and responsiveness thus resonate in Urry's reasoning. According to him, network capital is about being connected, making yourself connectable for capital enhancing purposes (Urry, 2007, p. 203), networking in other words. At the same time the aforementioned ideas of networking skills and digital literacy underline that not everyone is equally skilled/ prepared/ socially equipped in using social media platforms for accumulating such network capital. And this is concnerns how communication technologies are used rather than access to them.

The suggestion here is that Bourdieu's conceptual framework could inform a typology of capitals that could be used for studying networking power within activist demands in network societies, how certain come to occupy core positions and others not. I will therefore suggest a typology of four different, but overlapping forms of capitals: participating, mobilising, connecting and engaging capital.

Starting with participating capital, in southern Stockholm, the value of being active and engaged made it possible for certain activists to accumulate and use a type of participating capital when positioning themselves in the field. For example, many postings on Facebook revolved around having attended rallies and campaigns. Similarly, in Breindl and Gustafsson's (2011) study, individuals holding power in activist networks were generally the more active ones. The number of postings/actions of a user and their level of participation in a shared project has become a currency 
in many online environments (Bruns, 2008, p. 55). But being active was not enough to accumulate this capital. You had to be recognised for your participation. This explains the importance to update others on your participation and make it visible online. Such practices can thus be understood as acts of positioning within the activist field. This resonates in Biggar's (2010) study of crowdsourcing activities. He claims that taking part in such activities is about building one's online portfolio and leveraging one's cultural and social capital within a community (Biggar, 2010, p. 10). In southern Stockholm, to write to politicians, being their watchdog and bark as soon as they did something considered bad for the cause, was also a way to collect this participating capital. For such activities, activists needed to possess knowledge on how society and politics work (cultural capital) in order to appeal a decision as well as knowing were and how to find information (cultural capital) and a sense of knowing how to navigate the field (habitus). Here we can clearly see that there is an exchange between habitus, cultural and participating capitals.

While participation was considered important, there was another thing that was perhaps even more recognised in southern Stockholm, mobilising others. As discussed previously, there is a difference between peripheral activists and core activists along lines of who updated others and who were updated. Or in other words, there is a difference between those who are expected to be mobilised and reactive and those who are proactive and mobilising others. In southern Stockholm for example, one core activist was mentioned several times for what was labelled as an "infectious" engagement. Hence, what can be discerned here is a type of mobilising capital. Similarly, Breindl and Gustafsson (2011) refer to temporal elites whose power comes from the possibility of mobilising others. Indeed, the creation of online content is of small matter without a large enthusiastic audience to use the technology to its full potential (Kaye, 2011, p. 208). Thus, recognition is also about having a wider supporting group who can spread information through social networks and rapidly mobilise. 
I would like to differentiate here between mobilising within the demand and connecting outsiders to the demand. According to Castells $(2009$, pp. 45, 430) it is along lines of who has the ability to connect networks to each other that constitutes (networking) power in network societies. Online communication has enabled individuals to act as social switchboards, centre points for multiple changing and overlapping networks of interaction. Nodes/ activists that can act as switches between networks/ demands become fundamental sources of networking power. This relates to discussions of bridging social capital. In contrast to bonding social capital, bridging social capital refers to connections with weak ties (Granovetter, 1973; Putnam, 2000). The importance of bridges can be traced back to Heidegger and Simmel (discussed in Urry, 2007, pp. 31-32) who pointed at the possibility of bridges to bring streams, banks and land into each others neighbourhood, and hence reorganising the ways people moved within an area. In network theory, researchers have underlined bridging capital as most important for networking power because they give people access to new and different resources, not the least through connections with weak ties (Baym, 2010, p. 136). Weak ties are conceived of as resources since it is through such ties that new information/ opportunities reach in-groups of users, and it is through weak ties a community/group or demand can reach out to others (Granovetter, 1973; Wellman, 2001; Ellison et al., 2011). The activists I interviewed in southern Stockholm were all active in other demands at the same time as fighting for the bathhouse. Some activists explicitly tried to create connections between the bathhouse activists and other groups they participated in. I call this connecting capital. This capital can be accumulated if the information that a user posts goes viral. Bennett and Segerberg (2012) have discussed such easy-to-personalize action themes (memes) that travel through personal appropriation and spreading as connective action. This is clearly intertwined with creating visibility for a demand and being in a position to spread information online, things that are of pivotal importance for activists today. Connecting capital also implies that users need to gather connections in order for the information they post has the possibility to go viral. But connecting capital also has to do with stratified 
attention structures already existing within a network. Highly recognised users in the online attention economy determine what information gets spread or not (as Nahon and Hemsley, 2013, convincingly have argued). Their networking power makes them into gate-keepers of what information goes viral or not.

Barabási (2011) has criticised the notion of week ties in favour of intermediate ties. I find this notion helpful for further delineating connecting capital to something that I suggest labelling engaging capital. It is one thing to connect activists, groups, demands together, spread information and create visibility in connective information flows online, and another thing to engage these other activists in actions. According to Barabási, engaging others (to an activist demand for example) do not come from weak ties but from intermediate ties since users rarely pay attention to the weak ties in their networks, overflowing with updates and information from ever growing social networks. Here there is a difference between spreading information from others in your networks (connecting capital) and to act on calls for arms. And for this intermediary ties (and not weak ones) are important to understand who possesses the ability to engage other groups and activists to a demand. In Southern Stockholm for example an artist managed to engage her colleagues in an art barricade. Other examples are activists who also were active politicians (in the Green Party) and thus functioning as important intermediaries between activists and the political system. This reasoning further resonates in Breindl and Gustafsson's (2011) claim of the existence intermediary elites in contemporary societies.

All these capitals have ultimately to do with negotiating recognition as an activist, recognition that could be exchanged into a core position (depending on the habitus of the activist). For example, participation has to be displayed to, and recognised by, connections within the demand in order for accumulation of participating capital to take place. Mobilising capital can be accumulated if one is 
recognised as successful with mobilising ones network connections, i.e. getting other activists within the demand to act. Connecting capital can be accumulated if connecting other activists or groups outside of the demand to the cause and being recognised for this. And finally engaging capital can be accumulated if this connection is of that sort that these other groups and activists will be engaged in action in ways that others within the demand appreciate. Recognition thus concerns the evaluation of actions, participations and displays by others/ peers, and this is one area in which social media is important, for turning capital accumulation into recognition.

Insert figure 1 about here

The focus on recognition underlines the interdependence of individuals (here activists) in network societies. But this also has to do with an activist's skills and position in the network to begin with. In other words, an activist's habitus is of importance if being able to turn participation, mobilisation, connections and engagement over into a core position. Habitus also matters if able to use experiences and actions from other activist demands to accumulate capital within the particular demand under study (as the arrows in the figure above illustrates). Connecting and engaging capital clearly concerns putting connections from other demands to use within the demand under study. Participating capital can also be accumulated, with the help of habitus, from actions in other demands. Analysing recognition we thus have to consider previous experiences in order to understand why certain activists come to occupy core-positions. Or as Bourdieu (2010/1984, p. 105) frames it, agents enter the social field with previously acquired capital. In another text he discusses agents entry into a field already with a kind of legitimacy as agents from previous fields (Bourdieu, 1993, p. 100). In other words to discuss these capitals it is important to consider the in-group versus the out-group in the capital accumulation. The negotiation for recognition it seems could only take 
place within the demand (the in-group). However, some of the capitals discussed above were dependent on involving outsiders, such as connecting, engaging and to some extent participation capitals. In southern Stockholm it was apparent that activists' previous experiences were used to negotiate core positions. Activists who had a track record were for example often referred to in the interviews as important for the bathhouse demand. Examples from southern Stockholm range from being recognised as efficient runners of the cinema Tellus, reputation as having successfully led political actions, or having organised campaigns. The boundaries of an activist demand are thus very permeable.

Bourdieu (1987, p. 4) himself mostly talk about economic capital (the accumulation of money), cultural capital (the accumulation of qualification, education and knowledge), social capital (the accumulation of social relations) and symbolic capital (the accumulation of reputation). It is apparent by focusing on recognition that I am exploring the terrain of symbolic capital in Bourdieu's terminology. In information overloaded network societies, getting noticed is everything. Networking power underlines that this unequal distribution of attention and visibility influence others, actions and definitions of reality within a demand. Social media can thus be conceived of as sites for power struggles as they have specific mechanisms for the generation of recognition and visibility. Van Dijck (2013, pp. 13, 62) talks here about a popularity principle, important for users recognition, but also, underpinning a so-called attention economy of social media. This attention economy online is indeed stratified, as powerful media conglomerates are better in attracting attention than others (Fuchs, 2014, p. 82). Concerning activists demands I also argue that attention is unequally distributed among activists within the same demand. And on social media platforms, recognition is relatively easy to negotiate because here relations are counted, measured and put on display together with ones ability to attract and maintain relationships with (like-minded) others (van Dijck, 2013, p. 62). 
This argument is perhaps better illustrated if related to the notion of fitness in network theory (Barabási, 2011). If we take the notions of nodes and links in network theory and replaces nodes for activists and links for connections between activists, fitness would refer to an activist's ability to attract other activists and connect with them. Being recognised as an activist would make the activist more fit, in the sense of being more likely to attract the attention of other activists and form relationships with them. In information overloaded network societies, knowing who to trust and who to connect to, is increasingly based on agents past achievements and others evaluation of these (Urry, 2007, p. 221). Recognised activists will become even visible since others are more likely to stumble across them online, learn about them, connect and link to them and hence contribute to their on-going accumulation of recognition as the popularity principle postulates. For example, rather soon after having joined the bathhouse campaign I come to realise which were more esteemed simply by observing who was retweeted and whose Facebook-postings received links and likes. In this way recognition could also be understood as a measure of habitus, of who possessed a sense of knowing how to navigate the field of activists demand.

I have discussed here the differences the online makes for displaying and using recognition to negotiate core positions, not the least through popularity principle (van Dijck, 2013, pp. 62). But it was also apparent to me that the online was interlinked with the offline and not easy to separate. In the bathhouse demand for example activist participating in offline actions put them on display on their social media profiles. Information about, and call to arms for offline actions, were most often posted online. Hence, social media do not replace offline collective action and actions that involve spatio-temporal presence. Bourdieu (2010/1984, p. 81) claims that each field sets it highest price on the outcomes being created within it. In activist fields it is clearly the actions themselves that are the most desired outcome. Offline actions thus mattered as apparent in the elaboration of the typology 
above. It is one thing to be able to connect people/ groups/ demands online in order to spread information and increasing visibility for a demand. But it is another thing to engage these others in offline collective actions. In southern Stockholm mobilising capital was accumulated mostly by engaging demands sympathisers in offline actions. Indeed, activists' actions may only take place online (as in the case of hacktivism and Anonymous), but it seems to me that most activist actions still mainly take place offline. There is a difference between spreading information through networks connections online and to act offline and in activist demands it seems that offline actions are the more valuable for accumulating participating, mobilising and engaging capital. What is happening in today's network societies though is that such capital is mostly negotiated for recognition (displayed) online on social media platforms. It thus becomes increasingly difficult to separate the online from the offline here (as also others have argued, see Baym, 2010; Chadwick, 2013). Indeed as Chadwick (2013) argues, activist actions often combine online and real-space behaviours and impacts (p. 189) and activists often operate in hybrid media ecologies (p. 193) in which both online and offline media has a role to play.

\section{Conclusion}

To understand networking power within activists demands I have outlined a typology of activist capitals out of an argument that recognition is becoming increasingly important for understanding relations of power in network societies characterised by social media platforms that in turn are characterised by an attention economy and popularity principle. This typology could be used for studying networking power in terms of who come to occupy core positions in an activist demands. In other words, holding a core position is connected with knowing how to network, gaining recognition through participating, mobilising, connecting and engaging activists to the demand. This is dependent on the habitus of the activists, their luggage of previously learned skills and sense of knowing how network in order to navigate the fields of activism in a network societies. 
While far from a detailed account, the aim here was to contribute to the understanding of contemporary activist participation in network societies and how relations of power are still at play in the form of networking power, even though it has been widely claimed that the internet and social media lowers the threshold for political participation. By outlining a typology of capitals, exemplified with the activist demand in southern Stockholm, the aim has been to suggest a way to study why certain activists come to occupy core positions and others more peripheral positions. I hope this typology has provided some understanding for the complexity of positions and positionings in an activist demand in a network society, and the intricate workings of how positions are gained and upheld, even in an affluent Swedish neighbourhood amongst a relatively homogenous group of people. Indeed, the typology would probably have to be modified and developped if put to use in a heterogeneous setting populated by a more unequal crowd and context. Hence, the aim at this stage is not generalize but to suggest and hopefully to inspire further exploration into the complexities that may emerge when negotiating power today. Empirical studies are needed in which this typology will be put to use, be criticised and further developed. I for one will work with this in the future in order to more empirically and carefully map the distribution and volume of the different capitals here outlined in the bathhouse demand. However, this will be another article.

So what are the implications of these findings other that relations of power are still at play in activist demands today? First of all this typology has implications for the study of power in todays network societies. By conceiving power as relational and networked, evolving from exchanges between interdependent people and technologies allows us to move away from categorizing people who are powerful or not and instead focus on the diversity of mechanisms and interactions that enable power to be exercised. Indeed, as Chadwick (2013, p. 207) has argued, power is shaped by 
hybrid networks in which both social and technological nodes have agency in terms of their interdependence and interactive exchanges with other nodes in the network. Social media platforms are neither neutral nor a determinant of change.

Second I believe this indicates the importance of practices of updating in network societies. Networking power is time bound to the participation of the user. Hence, constant participation in the form of continuous practices of updating is mandatory for negotiating the recognition that is needed to occupy of core-positions. Activists in southern Stockholm, that had not participated for some time, lost recognition and thus also their core-positions. One activist for example complained that he had to start from scratch after having been offline a longer time. He was left behind in plans, discussions and had not participated in several events. As I have argued elsewhere (see Author) the logic of social media requires users to be present, archive connections, update and be updated. And as I have argued here, time spend on social media platforms could generate recognition through participating, mobilising, connecting and engaging capital.

However, time spent online is also contributing to the economic value of social media companies (van Dijck, 2013; Fuchs, 2014, p. 114). We should not forget that capitalist companies own social media platforms. There is another layer of power at play here, economic power and exploitation of visibility seeking and recognition accumulating social media users. Economic capital is accumulated for social media owners when users use these media, even if used to negotiate corepositions within a for example counter-capitalist political demand. Hence, it becomes apparent that social media practices are informed by the capitalist logic of the companies that owns these platforms and capitalise on users updating practices. A third implication thus is that being online and updating social media profiles with information, users are making themselves surveillable and exploitable for capitalist companies. The logic of updating thus feeds neatly into the logic of capital 
accumulation and the business models of social media companies. In this way participation and political expression, organisation and mobilisation becomes subsumed under economic capital (Boltanski \& Chiapello, 2005).

\begin{abstract}
About the Author
Dr. Jakob Svensson is holding a position of associate professor in Media and Communication Studies at Uppsala University, Sweden. Dr. Svensson directs the MA program in Digital Media and Society. His research focuses on two main areas, political participation on digital media platforms and mobile communication in developing regions.

E-mail: jakob.svensson@im.uu.se
\end{abstract}

\title{
References
}

M. Andersson and A. Jansson, 2012. Landsbygdens Globalisering. Medier, identitet och social förändring i nätverkssamhällets marginaler. Göteborg: Daidalos.

A.L. Barabási, 2011. "Introduction and Keynote to a Networked self, “ In: Z. Papacharissi (editor). A Networked Self. Identity, Community, and Culture on Social Network Sites, pp. 1-14. New York: Routledge.

N.K. Baym, 2010. Personal Connections in the Digital age. Cambridge: Polity Press.

W.L. Bennett and T. Amoshaun, 2009. "Identity, technology, and narratives. Transnational activism and social networks," In A. Chadwick and P.N. Howard (editors). Routledge Handbook of Internet 
Politics, pp. 146-260. London: Routledge.

L. Bennet, and A. Segerberg, 2012. "The Logic of connective action," Information Communcication and Society, volume 15, number 5, pp. 739-768.

Å. Bengtsson, 2008. Politiskt deltagande. Lund: Studentlitteratur.

L. Boltanski, and E. Chiapello, 2005. The new spirit of capitalism. London: Verso.

P. Bourdieu, 1985. "The Social Space and the Genesis of Groups," Theory and Society, volume 14, number 6, pp. 723-744.

P. Bourdieu, 1987. "What Makes a Social Class? On the Theoretical and Practical Existence of Groups," Berkeley Journal of Sociology, number 32, 1987, pp. 1-17.

P. Bourdieu, 1993. Kultursociologiska texter. Pierre Bourdieu i urval av Donald Broady och Mikael Palme. Stockholm: Brutus Östlings Bokförlag.

P. Bourdieu, 2010. Distinction. London: Routledge. Original work published 1984.

Y. Breindl, 2012. “The Dynamics of Participation and Organization in European Digital Rights Campaigning," JeDEM - eJournal of eDemocrcay and Open Government, volume 4, number 1, pp. 24-44.

Y. Breindl and F. Briatte, 2013. "Digital Protest Skills and Online Activism against Copyright 
Reform in France and the European Union,” Policy and Internet, volume 5, number 1, pp. 27-55.

Y. Breindl and N. Gustafsson, 2011. "Leetocracy: Networked political activism and the continuation of elitism in competitive democracy," In D. Araya and Y. Breindl and T.J. Houghton (editors). Nexus: New Intersections in Internet Research, pp. 193-212. New York: Peter Lang.

J. Biggar, 2010. "Crowsourcing For the Environment: The Case of Brighter Planet," Platform: Journal of Media and Communication, volume 2, number 2, pp. 8-23.

A. Bruns, 2008. Blogs, Wikipedia, Second Life, and Beyond. From Production to Produsage. New York: Peter Lang.

N. Carpentier, 2011. Media and Participation. A Site of Ideological-Democratic Struggle. Bristol: Intellect.

M. Castells, 2000. Informationsåldern. Ekonomi, samhälle och kultur. Band 1. Nätverkssamhällets framväxt. $2^{\text {nd }}$ Edition. Göteborg: Daidalos.

M. Castells, 2009. Communication Power. Oxford: Oxford University Press.

M. Castells, 2012. Networks of outrage and hope. Social Movements in the Internet Age. Cambridge: Polity Press.

A. Chadwick, 2013. The Hybrid Media System. Politics and Power. Oxford: Oxford University Press. 
P. DiMaggio, and E. Hargittai, and C. Celeste, and S. Shafer, 2004. ”Digital Inequality: From Unequal Access to Differentiated Use," In. K.M. Neckerman (editor). Social Inequality, pp. 355400. New York: Russell Sage Foundation.

N. Elias, 1998. “The Social Constraint towards Self-Constraint,” In S. Mennell and J. Goudsblom (editors). Norbert Elias. On Civilization, Power and Knowledge, pp. 49-66. Chicago: The University of Chicago Press. Original work published 1939.

N.B. Ellison and d. boyd, 2007. "Social Network Sites: Definition, History and Scholarship," Computer-Mediated Communication, volume 13 number 1

N.B. Ellison and C. Lampe and C. Steinfield and J. Vitak, 2011. "With a Little Help from My friends: How Social Network Sites Affect Social Capital Processes,” In Z. Papacharissi (editor). A Networked Self. Identity, Community, and Culture on Social Network Sites, pp. 124-145. New York: Routledge.

P. Esaiasson and A. Westholm 2006. Deltagandets mekanismer: det politiska engagemangets orsaker och konsekvenser. Malmö: Liber.

A. Feenberg, 2010. Between Reason and Experience. Essays in Technology and Modernity. 
Cambridge: The MIT Press.

C. Fuchs, 2014. Social Media. A Critical Introduction. London: Sage.

Granovetter, M. S, 1973. “The Strength of Weak Ties, ” American Journal of Sociology, volume 78, issue 6, pp. 1360-1380.

M. Gui, and G. Argentin, 2011. ”Digital Skills of Internet Natives: Different Forms of Digital Literacy in a Random Sample of Northern Italian High School Students," New Media and Society, volume 13, number 6, pp. 963-980.

E. Hargittai, 2008. "The Digital Reproduction of Inequality,” In. D.B. Grusky in collaboration with M.C. Ku and S. Szelényi (editors). Social Stratification: Class, Race, and Gender in Sociological Perspective, pp. 936-944. Boulder: Westview Press.

E. Hargittai, and A. Hinnant, 2008. 'Digital Inequality. Differences in Young Adults Uses of the Internet," Communication Research, volume 35, number 5, pp. 602-621.

Y.P. Hsieh, 2012. “Online social networking skills: The social affordances approach to digital inequality," First Monday, volume 17, number 4, available at http://firstmonday.org/htbin/cgiwrap/bin/ojs/index.php/fm/article/viewArticle/3893 accessed 13 December 2013.

H. Jenkins, 2006. Convergence culture. Where old and new media collide. New York: New York University Press. 
H. Jenkins, and S. Ford and J. Green, 2013. Spreadable media. Creating Value and meaning in a networked Culture. New York: New York University Press.

A.M. Kaplan and M Haenlein, 2010. "Users of the world, unite! The challenges and opportunities of social media,” Business Horizons, volume 53, number 1, pp. 59-68.

B.K. Kaye, 2011. "Between Barack and a Net Place. Motivations for Using Social Network Sites and Blogs for Political Information," In Z. Papacharissi (editor). A Networked Self. Identity, Community, and Culture on Social Network Sites, pp. 208-231. New York: Routledge.

E. Laclau, 2005. On Populist Reason. London: Verso.

C. Mouffe, 2005. On the Political. London: Routledge.

K. Nahon and J. Hemsley, 2013. Going Viral. Cambridge: Polity.

OECD, 2010 (March). Are New Millennium Learners Making the Grade? Tech- nology Use and Educational Performance in PISA 2006. Retrieved from http:// www.oecd-

ilibrary.org/education/are-the-new-millennium-learners-making-the-grade_9789264076044-en, May 16,2012.

T. O'Reilly, 2005. "What is Web 2.0. Design Patterns and Business Models for the Next Generation of Software”, oreilly.com/web2/archive/what-is-web-20.html. Accessed 10 January 2013. 
R.D. Putnam, 2000. Bowling Alone: The Collapse and Revival of American Community. New York: Simon and Schuster.

C. Shirky, 2009. Here Comes Everybody. How Change Happen when People Come Together. London: Penguin Books.

J. van Dijck, J. 2013. The Culture of Connectivity: A Critical History of Social Media. Oxford: Oxford University Press.

J. van Dijk, 2006. The Network Society. 2nd edition. London: Sage.

J. Urry, 2007. Mobilities. Cambridge: Polity Press.

B. Wellman, 2001. "Physical Place and CyberPlace: The Rise of Personalized Networking," International Journal of Urban and Regional Research, volume 25, number 2, pp. 227-252. 